\title{
Discussion on the Historical Laws of Productivity Development and Its Contemporary Manifestations
}

\author{
Qichun Liu \\ The Institute of Marxism of Hubei University of Chinese Medicine, Wuhan City, Hubei Province, zip \\ code 430065, China.
}

liuqichunwu@126.com

\begin{abstract}
This paper analyzes the historical law of the development of productive forces from the inner contradictory movement law and intelligent evolution law, and reveals the scientific and intelligent trend of the development of productive forces. This paper hopes to arouse the attention of the academic circle to the inherent law of productivity development.
\end{abstract}

Keywords: Productivity; scientific; intelligent; law of development.

\section{Introduction}

The law of productive forces development includes the law of historical inheritance, division of labor coordination, social history and dynamic balance. There are many academic researches, but most of them are scattered. This paper discusses the historical law of productivity development from the inner contradictory movement law and intelligent evolution law. On this basis, we also studied the contemporary expression of the knowledge-based and intelligent trend of productivity development in the aspects of laborers, labor materials, labor objects, etc., in the hope of attracting the attention and attention of academic circles to the inherent law of productivity development.

\section{Marx: the Development of Productive Forces Has Objective Regularity}

In analyzing the process of the basic contradiction movement of human society, Marx regarded the development of social form as a natural historical process and solved the "riddle of history" for the first time. Lenin also pointed out that "when the productive forces are derived from social relations and production relations, the development of social forms can be understood as a natural historical process."[1] it can be seen that classic Marxist writers all agree with the objective and inevitable regularity of productivity development without reservation.

First, Marx demonstrates the objective regularity of the development of productive forces from the point of view that the productive forces are the total source of all social changes. The development of human society is the result of the development of social productive forces. From the stone tools of primitive society to the bronze ware of slave society to the use of iron in feudal society, all reflect this rule. And the capitalist system replaced the feudal system, the use of machine production has played a decisive role. Marx analyzed and clarified that social productivity is the decisive force for social development and the ultimate cause of all social changes. In other words, the objective regularity of productivity development determines the law of change of production relations and the law of superstructure reform.

Secondly, Marx demonstrated the objective regularity of productivity development from the perspective of economic entities such as labor materials during the development of productivity. Marx writes, "the revolutionary class itself is one of the most powerful productive forces."[2] "labor data can not only measure the progress of human labor force development, but also indicate various social relations generated in the process of labor. Moreover, the mechanical means of labor are more likely to show the characteristics of an era of social production. [3] therefore, it is on the basis of the objective law of the development of productivity that human relations of production and the law of superstructure's movement development are realized and completed.

Thirdly, productivity always operates according to its inherent objective laws. This has been proved beyond doubt by the development history of human society. As the most active and 
revolutionary factor, "the development of productivity is the development of material strength". [4] it determines not only the change of social form, but also the development of human society. The structure, nature and appearance of a society depend on the development of productive forces. The transformation of social productive forces will inevitably lead to changes in production relations and social structure. These are the objective regularity of productivity development.

\section{The Historical Law of the Development of Productive Forces}

In the process of human history development, as the most active positive factor, productivity is not a dependent variable, but an independent variable; It not only has the motive power of internal contradiction development movement, but also contains the special self-organization system. Its internal laws guide its development and changes at every stage. In essence, the inner contradictory movement rules and intelligent evolution rules of productivity development enable knowledge and intelligence to activate other components of productivity. This greatly promotes the production and development of modern society.

\subsection{The Internal Law of Contradictory Movement of Productivity Development}

It is well known that the basic contradictions of human society exist in all social forms. It is the contradictory movement between productive force and productive relation, economic base and superstructure. It defines the nature, structure and aspect of society. This dialectical movement of mutual connection, mutual restriction and interaction has become the ultimate driving force for the development of the whole society. This makes the law that human society develops gets full body. Nevertheless, the self-movement of the productive system comes from the internal contradictory movement of the subject-the contradiction between the subject and its developing needs and the object's need to the subject.

As long as it is human, it has the nature of need, which is one of the natural characteristics of human. Generally speaking, material needs and spiritual needs are two aspects of human needs. Obviously, the former is the premise and foundation of the latter, and the acquisition and satisfaction of the latter will in turn promote the improvement and development of the former. Human needs are social history and dynamic development. That is to say, people's needs are not constant and static, but changing dynamically with the changes of times and the development of productivity.

Since the emergence of human beings, the development of productivity from low level to high level has roughly experienced The Times of manual production (including stone tools, bronze ware and iron ware), The Times of large machine production and The Times of intelligent production. Accordingly, the level of human needs has gone through the development process from lower level to higher level, from one-sided to comprehensive. It can be said that every improvement in the level of human needs promotes the development and progress of human productive forces to some extent. On the contrary, almost every production progress, will also promote the level of human needs. This contradictory movement is pushing forward the development of human society.

\subsection{Intellectual and Intelligent Evolution Rules of Productivity Development}

Intellectual and intelligent evolution rules of productivity development the history of human society is always inseparable from the accumulation and development of knowledge. Therefore, it is the generation and development history of knowledge. Any change and development with great significance of progress, for productivity, is rooted in the innovation of knowledge. Thus, human history is also an evolutionary history of productivity. This shows the intelligent evolution rule of productivity development.

In the long history of the development of productive forces, with the changes of times and the accumulation and development of human knowledge, the core resources that determine the development of productive forces in each era are different. In general, core resources are often scarce at the time. In the course of social development, the status of knowledge has been gradually improved and its role has become more and more important. Knowledge is also becoming more and more 
important in factors of production. That is to say, accumulated knowledge gradually becomes the most creative and valuable core resource, and determines human economic growth and social development. In this way, the status of knowledge has undergone a revolutionary change in the structure of productivity systems after a historical evolution process from lower to higher, from quantitative to qualitative, from weak to strong and then to dominant. The scientific and intelligent evolution rule of human productivity development has also been fully shown. [5]

\section{The Contemporary Expression of Scientific and Intelligent Trend of Productivity}

Productivity is a historical category, not a constant, rigid concept. It is itself an independent variable. It will change its content constantly with the development of history. With the rapid development of science and technology, especially the rise of network economy, knowledge, intelligence and information are becoming the most important core resources. They not only instigate and inspire the productive forces to exert great functions and stimulate the productive forces function of knowledge, but also highlight the scientific and intelligent trend of contemporary productive forces development. This is in laborer, labor data, labor object and so on aspect has behaved.

\subsection{The Trend of Physical Laborers Gradually Transforming Into Knowledge-Based Laborers}

In the process of production, the labor ability of the laborer to exert the labor function and production function, generally speaking, including physical ability, intellectual ability and psychological ability. Since modern times, the development of natural science, especially the use of steam engine, textile machine and telegraph machine, has greatly promoted the progress of productivity. The trend that "physical strength type" laborer just begins to turn gradually to "intellectual strength type" laborer. With the rise and vigorous development of computer network technology, various elements of productivity are becoming more and more "soft". People's way of working and way of communication have undergone revolutionary changes. Artificial intelligence directly or indirectly replaces manpower. The working proportion, social function and social status of "manual laborers" and "knowledge laborers" have been replaced. Whether qualitative aspect or quantitative aspect, knowledge worker has become the main body of social labor force. In the knowledge economy society, the function and status of research and development labor is much higher than that of processing and manufacturing labor. Because the "knowledge" content of research and development labor replaces the material or physical labor that used to make up the product. It determines the value of the product to a greater extent. That is to say, the internal quality of workers has become a significant variable to improve productivity.

\subsection{In Terms of Labor Data, the Role of Knowledge-Based Labor Data Is Showing An Increasing Trend}

Labor data is by no means unchanging. It will develop and change with the change of times, especially the progress of science and technology. Modern production tools show the trend and trend of intelligence, network and informatization. This reflects the main characteristics of modern knowledge-based labor data. In today's era, the knowledge content of labor information system shows a trend of continuous improvement. It is more and more clearly showing the characteristics of intelligence, networking, digitalization and informatization. In short, the division and differentiation of knowledge not only promote the development of productivity and social progress; Moreover, knowledge can be combined with other factors of production to form new composite factors of production. It promotes the intellectualization and intellectualization of modern labor data to be higher and higher (see the table below for details). [6] 
Table 1. Table of knowledge attribute and form classification of production factors

\begin{tabular}{|c|c|c|c|c|c|}
\hline \multicolumn{2}{|c|}{ Factor classification } & $\begin{array}{c}\text { Intellectual } \\
\text { property }\end{array}$ & Example & $\begin{array}{c}\text { Producing } \\
\text { method }\end{array}$ & Cause \\
\hline \multicolumn{2}{|c|}{ material factors of production } & $\begin{array}{l}\text { Knowledge } \\
\text { free attribute }\end{array}$ & $\begin{array}{c}\text { Sunlight, water } \\
\text { and soil, air, } \\
\text { minerals }\end{array}$ & Nature effect & natural production \\
\hline \multicolumn{2}{|c|}{ Knowledge production factor } & ideology & $\begin{array}{l}\text { Process, } \\
\text { formula, } \\
\text { software, } \\
\text { information }\end{array}$ & $\begin{array}{l}\text { Operation of } \\
\text { thinking }\end{array}$ & $\begin{array}{l}\text { Division of } \\
\text { knowledge }\end{array}$ \\
\hline \multirow{2}{*}{$\begin{array}{l}\text { The } \\
\text { composite } \\
\text { elements }\end{array}$} & $\begin{array}{l}\text { Knowledge- } \\
\text { based elements }\end{array}$ & ideology & $\begin{array}{c}\text { Human capital, } \\
\text { management } \\
\text { system }\end{array}$ & $\begin{array}{l}\text { Operation of } \\
\text { thinking }\end{array}$ & \multirow[b]{2}{*}{$\begin{array}{l}\text { Knowledge of } \\
\text { composite }\end{array}$} \\
\hline & $\begin{array}{c}\text { Physicochemical } \\
\text { element }\end{array}$ & $\begin{array}{l}\text { Materialized } \\
\text { form }\end{array}$ & $\begin{array}{l}\text { Machine } \\
\text { equipment, } \\
\text { intermediate } \\
\text { products }\end{array}$ & $\begin{array}{c}\text { Knowledge } \\
\text { materialization }\end{array}$ & \\
\hline
\end{tabular}

\subsection{In Terms of Labor Objects, the Fields and Scope of Knowledge Labor Objects Show An Increasingly Extensive and Profound Trend}

As the basic condition of the production of material products, material and energy are the important elements of the object of labor. In modern times, new materials, new energy and so on emerge in endlessly. This reflects the extensive and novel tendency of knowledge-based labor objects. The actual production consumes less and less material, and more and more knowledge virtual material (knowledge and information). Moreover, as a new strategic resource that dominates the development of productivity, human resources such as information and knowledge have gradually become a novel object of labor. They have greatly expanded the field and scope of the object of labor and enriched the object of Labor Day by day. They make it both the most subtle and detailed part of life and the vastness of the universe. In addition, the object of labor can be digital, electronic, network and knowledge information itself.

\subsection{Human Production and Labor Are Becoming More and More of The Trend of Knowledge Labor}

The so-called knowledge labor, in general, refers to the general term of the activities of knowledge production, communication and application around social knowledge. The Labor Day of human life is transformed into knowledge labor. This is the most far-reaching revolutionary change in the world today. Unlike the nature of direct labor, knowledge labor has become a different economic society phenomenon in new times. In all history, the basic labor form of human beings has changed dramatically. From the original "gathering" to the direct labor of the age of material production, and the knowledge of the general development of the present age, there is no scientific assertion that "labor is the first basic condition of human life." In the knowledge economic society, all kinds of activities around social knowledge are an important part of knowledge labor.

\section{References}

[1]. Selected works of Lenin, vol. 1, Beijing, people's publishing house, 1995.

[2]. Complete works of Marx and Engels, vol. 4, Beijing, people's publishing house, 1979.

[3]. Complete works of Marx and Engels, vol. 23, Beijing, people's publishing house, 1979.

[4]. Selected works of Lenin, vol. 1, Beijing, people's publishing house, 1995.

[5]. Liu Sichuan and Chen Jianhua, on the evolution and dialectical relationship of knowledge in the structure of productivity, Jianghan BBS, 2016, no. 3. 
[6]. Liu Sichuan, theory of knowledge productivity, Changsha, Hunan people's publishing house, 2017.

[7]. Selected works of Marx and Engels, vol. 3, Beijing, people's publishing house, 1972. 